\title{
Feeding Strategies of the Guiana Dolphin Sotalia guianensis
}

\author{
Marcos R. Rossi-Santos ${ }^{*}, 1, \S$ and Paulo A.C. Flores ${ }^{2}$ \\ ${ }^{1}$ Centro de Ciências Biológicas, Universidade Federal de Santa Catarina and International Wildlife Coalition, Brasil \\ ${ }^{2}$ Centro Nacional de Pesquisa, Conservação e Manejo de Mamiferos Aquáticos - CMA, ICMBio CMA SC - Rod. \\ Maurício Sirotsky Sobrinho, s/n, km02, Jurerê, Florianópolis, SC, 88053-700, Brasil
}

\begin{abstract}
The aim of this study was to characterize the feeding behavior of the Guiana dolphin, S. guianensis, through description and quantification of the strategies used by the dolphins, and possibly to apply this patterns to other areas in its distribution. Data were collected during systematic boat surveys, between November/1996 and May/1997, with 120 hours and 13 minutes of total observations. Scheffé Test was utilized to determine whether some strategies were used more than others. Six basic strategies of dolphin feeding behavior were identified: Individual Random Feeding (IRF), Group Random Feeding (GRF), Circular Cooperative Feeding (CCF), Front Cooperative feeding (FCF), Crossing Cooperative Feeding (CRF) and Zig-zag Cooperative Feeding (ZCF). The strategy GRF was statistically different from the others (Scheffé 5\%). Previous studies suggested that S. guianensis exhibit two basic feeding strategies, while here we show greater diversity on the feeding behavior, with more complex and varied foraging strategies than previously reported for this species. Observed variation in the coordination of individuals, group cohesion, movement patterns, prey availability and environmental features, demonstrates the complexity of the $S$. guianensis feeding behavior.
\end{abstract}

Keywords: Feeding behavior, Strategies, Guiana dolphin, Sotalia guianensis.

\section{INTRODUCTION}

Animal species posses a diversified array of strategies to overcome the defenses of prey species that are difficult to locate or capture, likewise social living may, in some cases, aid in food location or capture. Group foraging, which is at times cooperative can late increase capture rates and a higher feeding and resulting in more success for all the participants $[1,2]$.

Cetaceans present a great complexity and variety in their feeding behavior, but, like other animals, they also obtain their food with some standardized procedures, with the finality of maximize the success of each attack (e.g., [3-6]).

Cooperative feeding strategies have been reported for various cetacean species. Examples include the killer whale Orcinus orca [7-10], the bottlenose dolphin, Tursiops truncatus (e.g. [3, 11-15]), the spinner dolphins, Stenella longirostris [16, 17], the franciscana, Pontoporia blainvillei [18], Humpback whales Megaptera novaengliae [19-21] and some multi-species groups (e.g. [6, 22]).

The Guiana dolphin, Sotalia guianensis (for adopted name see [23-25]) occurs continuously along the Atlantic coast of Central and South America [26] from Nicarágua [27] to Santa Catarina state, Southern Brazil [28]. Despite

\footnotetext{
*Address correspondence to this author at the Instituto Baleia Jubarte. Avenida do Farol, s/n, C.P. 92, Praia do Forte, Mata de São João, Bahia, 48280-000, Brasil; Tel: 55713676 1463; Fax: 55713676 1463; E-mails: marcos.rossi@baleiajubarte.org.br, mrosantos@pop.com.br

${ }^{\S}$ Present Address: Instituto Baleia Jubarte. Avenida do Farol, s/n, C.P. 92, Praia do Forte, Mata de São João, Bahia, 48280-000, Brasil
}

many studies of this species (e.g. [29-33]), there is little detailed information on feeding behavior. Two basic types of feeding strategies for the Guiana dolphin were initially described: random fishing and cooperative fishing [29, 34]. These feeding descriptions have been commonly used and accepted in previous reports $[35,36]$.

The aim of this study was to characterize the feeding behavior of the Guiana dolphin, S. guianensis in southern Brazil, through description and quantification of the strategies used by the dolphins.

\section{MATERIALS AND METHODS}

In the southern limit of $S$. guianensis distribution, the North Bay of Santa Catarina waters, southern Brazil, there is a resident population that has been studied since 1991 . There, estuarine dolphins show a high site fidelity to specific zones within their range, especially a small cove called Enseada or Praia dos Currais [37], where they feed, mate, nurse calves and rest.

The North Bay of Santa Catarina (Fig. 1) is located between Santa Catarina Island and the mainland, with mean depth less than $12 \mathrm{~m}$, sandy substrate and some flagstones. There are eight islands and shores cut out by sandy beaches, rocky coasts, mangroves, Atlantic Forest and urban areas. The Environmental Protection Area of Anhatomirim, was created by the Federal law n ${ }^{\circ}$ 528/ 1992/May/20, with the main goal to protect the resident dolphins' population, the remaining Atlantic Forest and the rivers and streams in the area. Located in the EPA's heart, the Enseada dos Currais (Fig. 1) is an approximately $1 \mathrm{Km}$ cove, with maximum depths of about 5 $\mathrm{m}$, sandy-siltic bottom, two sandy beaches, three rock coasts and a small island at the north point of the bay. 


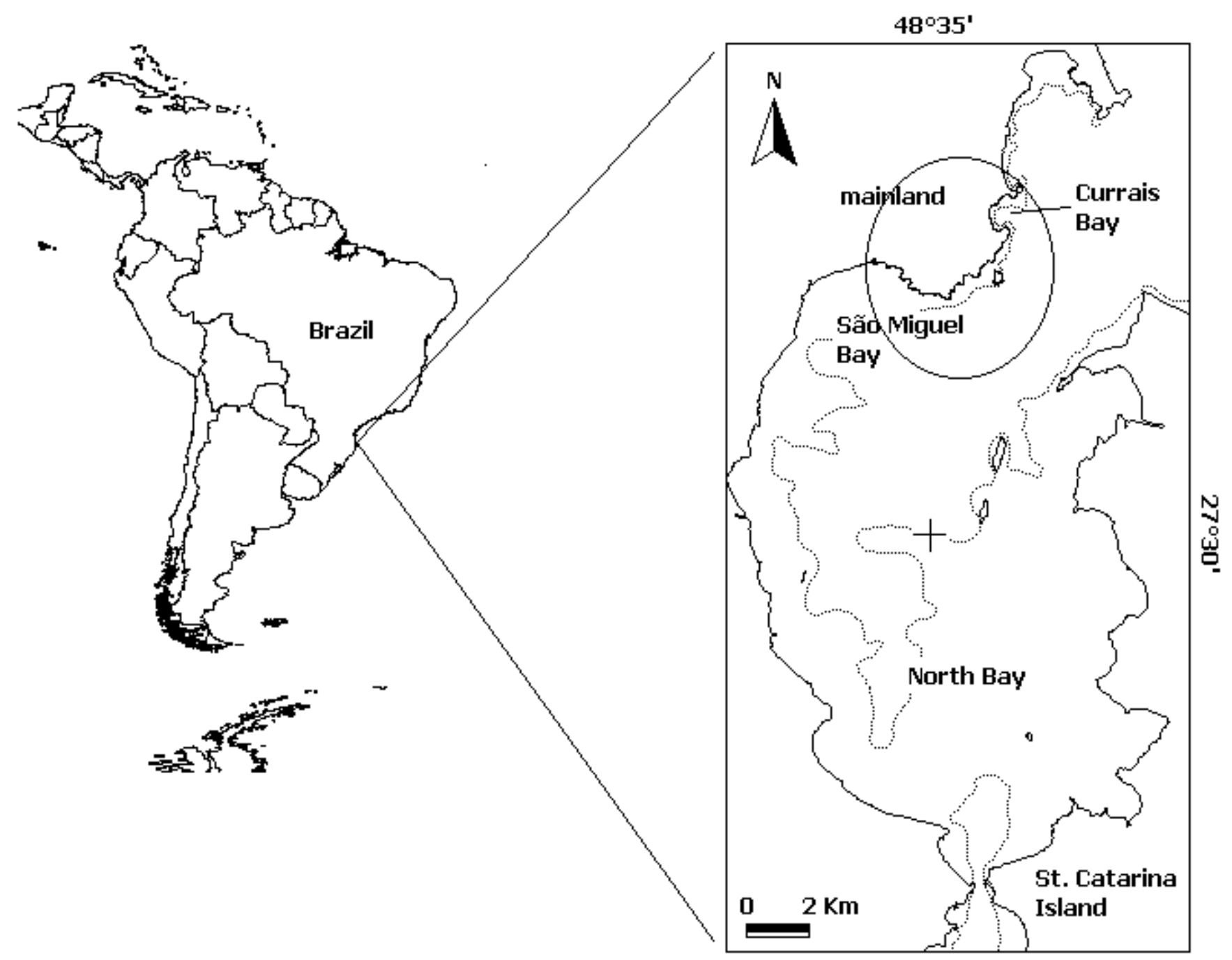

Fig. (1). Map of the study area, the North Bay of Santa Catarina, Brazil (circle represents the EPA Anhatomirim).

Data were collected during systematic boat surveys (4 m inflatable boat with 15 or $25 \mathrm{Hp}$ engines) (see [38]) to study the feeding behavior of Sotalia guianensis in the North Bay. Land observations were also conducted from shore stations located at the North Coast and Praia dos Currais, both 2 to 3 $\mathrm{m}$ high (Fig. 1). A focal group sampling method was used when the focus was the activity of the entire band, accompanied by naturalistic observations [39]. All feeding strategies were registered in 5 minutes interval sampling. Group sizes (number of individuals) were estimated by direct counting of the maximum animals seen at surface at one time, using the same categories described by [35].

Concerning terminology, the word "band", represents the largest group ever observed of $S$. guianensis (more than 60 individuals), while the word "group" corresponds to a division of the band (11-60 individuals). Finally, the term sub-group reefers to smaller group sizes (2 a 10 individuals).

Between November 1996 and May 1997, 15 surveys were taken with 120 hours and 13 minutes total effort of observation and 72 hours and 43 minutes of direct observation of the dolphins. Before this period, beginning in 1994, another 15 surveys were taken with ad-libitum and naturalistic observations [39].
Data were analyzed by observing the proportion of time in which the animals were performing the feeding strategies described bellow. The Scheffé Test was utilized to determine whether some strategies were used more than others.

\section{RESULTS}

\section{Feeding Strategies Descriptions}

Six basic patterns of dolphin feeding behavior were identified and characterized. These strategies were distinct one from each other, recognizable since started.

1. Independent or Individual Random Feeding (IRF) Dolphins are distant apart and randomly dispersed either alone or in subgroups of 2 to 5 individuals, without any defined direction. They seem not to have either cooperative or coordinated organization, keep on moving in several directions in an erratic way. Individual feeding behavior like assaults and bursts in the surface are common. It corresponds to the random fishing described earlier (e.g. [29]).

2. Group Random Feeding (GRF) - Here, the animals are moving in different directions, but in larger subgroups with 6 to 10 individuals, quite more 
cohesive. Sometimes all the band splits in two groups of 20-30 individuals in opposite directions, and afterwards unite themselves again. It is frequent this kind of strategy comes before the cooperative ones. Individual behavior occurs like jumps, assaults and bursts on the surface. This strategy may also occur associated to traveling behavior.

3. Front Cooperative Feeding (FCF) - This strategy is commonly used to drive the fish' schools to shallow waters either to the coast or to another group of dolphins, coming like a wall or barrier. During this strategy the entire band can participate either in front formation or in separated groups. Dolphins move very close and side by side in a same direction, when suddenly they swim in various directions, supposed to capture the preys. Quickly they restart the traveling in a same direction.

The dolphins were observed many times performing FCF movement in and out of the Enseada dos Currais, entering in a more united and parallel way. The band could enter the cove in a front formation and divides in smaller subgroups of 5 to 10 individuals, one after the others, but all moving in the same direction. This strategy can be seen associated to traveling activity, with the dolphins changing the direction, sometimes closer between themselves and other more separated.

4. Circular Cooperative Feeding (CCF) - Animals forming groups of more that 20 individuals, and afterwards divided in subgroups of 4 to 10 , organizing themselves in circles and converging all to the center in simultaneous dives, dispersing soon after for reinitiate again to form circles and diving. Usually they surround the school to keep the fish moving in circles that are gradually narrowed by the dolphins. It is common the occurrence of individual behavior like many assaults, bursts and lifting tail in the surface. A few jumps occur during this strategy.

5. Crossing Cooperative Feeding (CRF) - This kind of coordinated strategy shows a crossing movement pattern between groups of dolphins (10 to 30 individuals), swimming in opposite directions, in a way that fish stay enclosed in the middle of the crossing routes of the dolphins. This strategy occurs either close to the beach and the rocky shores or in the middle of small bays, generally in shallow areas. Jumps, assaults, bursts and lifting tail on the surface can be noticed.

6. Zig- zag Cooperative Feeding (ZCF) - Particularly in February 21, 1997, the dolphins showed a coordinated strategy pattern that until this date had not been observed. The band was very cohesive and moved in blocks with cris- crossing rout, all in the same direction, going on and coming back in a short extension (100 meters). The group cohesion was remarkable and they spent 80 minutes feeding through this strategy. It was not observed, during this time, any kind of aerial behavior, only some tail slap and lifting on the surface.

Besides the above described strategies, the dolphins often did a mix of two or more strategies and to make the description of the cooperative strategies much more complex, it was noticed that the most of them showed variations on the movement patterns, within each strategy, resulting in differentiated formations. In many occasions, mainly in the cooperative strategies, it was possible to observe jumping fish among the groups of dolphins.

About number of individuals, in most of surveys, the strategies were performed by the entire band $(>60$ individuals) acting cooperatively and showing a great complexity of social interactions. Sometimes groups of 30 to 40 animals did some of the coordinated strategies, while others stayed in the intermediate strategies of search for fish (see GRF).

\section{Statistical Results}

Scheffé test identified differences between each one of the feeding strategies performed by $S$. guianensis in the study area (Table $\mathbf{l}$ - different letters after means).

Table 1. Time of Occurrence $(\min =$ Minutes) Observed for the Feeding Strategies Used by Sotalia guianensis, During the Study Period

\begin{tabular}{|c|c|c|c|c|}
\hline $\begin{array}{c}\text { Feeding } \\
\text { Strategies }\end{array}$ & $\begin{array}{c}\text { Mean* (min) } \\
\text { of the Study } \\
\text { Months }\end{array}$ & $\begin{array}{c}\text { Standard } \\
\text { Deviation }\end{array}$ & $\begin{array}{c}\text { Minimum } \\
\text { (min) }\end{array}$ & $\begin{array}{c}\text { Maximum } \\
\text { (min) }\end{array}$ \\
\hline \hline CCF & $30,5 \mathrm{a}$ & 36,2 & 0 & 100 \\
\hline IRF & $49,8 \mathrm{a}$ & 35,6 & 13 & 104 \\
\hline $\mathrm{CRF}$ & $98,7 \mathrm{ab}$ & 44,9 & 36 & 156 \\
\hline $\mathrm{FCF}$ & $168,2 \mathrm{~b}$ & 56,4 & 98 & 236 \\
\hline $\mathrm{GRF}$ & $304,7 \mathrm{c}$ & 46,9 & 241 & 368 \\
\hline
\end{tabular}

All the 5 analyzed strategies were observed during the 6 months of observation." Means followed by different letters are significantly different (Scheffé $\mathrm{p}<0.05$ ).

Analyzing Table 1, in order to compare the occurrence of strategies, was noticed that the mean of the observed times of occurrence for CCF, IRF and CRF strategies was not statistically different.

The same happened was showed between CRF and FCF strategies. Nevertheless, the occurrence of the FCF strategy was significantly different from others (CCF, IRF, GRF), as well as the GRF strategy, that showed significant statistical difference when compared to all others.

The standard deviation of different strategies was showed as inversely proportional to the mean's values, with bigger means presenting smaller deviations. The uniformity of the observed time of occurrences can be better understood looking at the maximum and minimum values for each strategy (Table 1).

Estimated error value ( $\mathrm{p}$ value) was $0,0001 \%$ because these samples were collected randomly. This confirms that really exist differences in the observed times of each strategy.

The line graph (Fig. 2) shows the differences in the strategies' observed times of occurrence in the months of study. Attention to the high values of GRF that presents a relatively small standard deviation, when compared to the standard deviation of other strategies. On the other hand, 


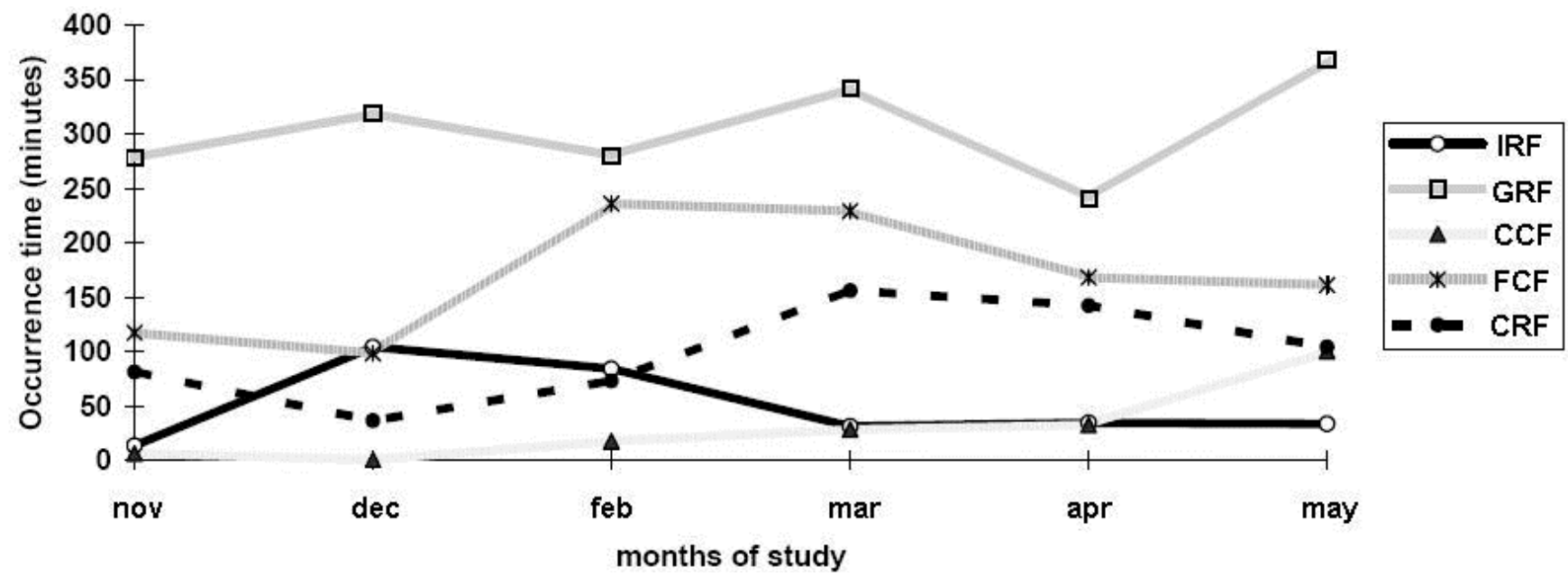

Fig. (2). Occurrence time observed (minutes) for the feeding strategies utilized by Guiana dolphins, Sotalia guianensis, North Bay of Santa Catarina, during the months of study.

FCF strategy varied from small values in the first study month, increasing in December and February, to decline in the following months.

This graph also shows the similarities of the occurrence times of FCF, CRF and IRF strategies, that has similar values, crossing themselves along the months, and in a certain moment of the graph progression, in the April and May months, the times of occurrence of IRF and CRF strategies were almost the same.

Analyzing the relative frequencies graph, of time occurrence of IRF and GRF strategies (Fig. 3), it is possible to notice that GRF strategy was uniformly distributed along the study months, with frequencies not variable, from $13 \%$ in April to $20 \%$ in May.

On the other side, in the same graph we could see that the frequency of IRF strategy has varied irregularly, presenting a peak in December/96 (35\%), keeping high in February/97 $(29 \%)$ and decreasing in the other months $(4,3 \%$ in November/96 and varying from 10 to $11,2 \%$ between March and May/97) (Fig. 3).

In Fig. (4), comparing the relative frequencies of times of occurrence with the three analyzed coordinated or cooperative strategies, was noticed that the largely distributed along the months was PCL, with the frequencies varying from $10 \%$ (December/96) to $23,4 \%$ (February/97); from February to May/97 the difference between frequencies of PCL's times was smaller $(23,4 \%$ in February and $16 \%$ in May/97).

The CRF strategy was the most frequent of the three coordinated strategies, during November/96, March and April/97, with highest frequency registered in March/97 $(26,4 \%)$.

Looking at CCF strategy, it was verified an irregular distribution of frequencies, with small values in November/96 (3\%) and February/97 (9\%), with a frequency of times of occurrence equal to zero in December/96 and a peak in May/97 (55\%), during it was the most frequent of the three coordinated strategies analyzed.

\section{DISCUSSION}

Previous studies suggest that $S$. guianensis presents two basic kinds of feeding strategies: random and cooperative feeding (e.g. [29, 34]). In the present study it was observed greater diversity on the feeding behavior, in a complex variation of strategies at relatively simple methods of prey

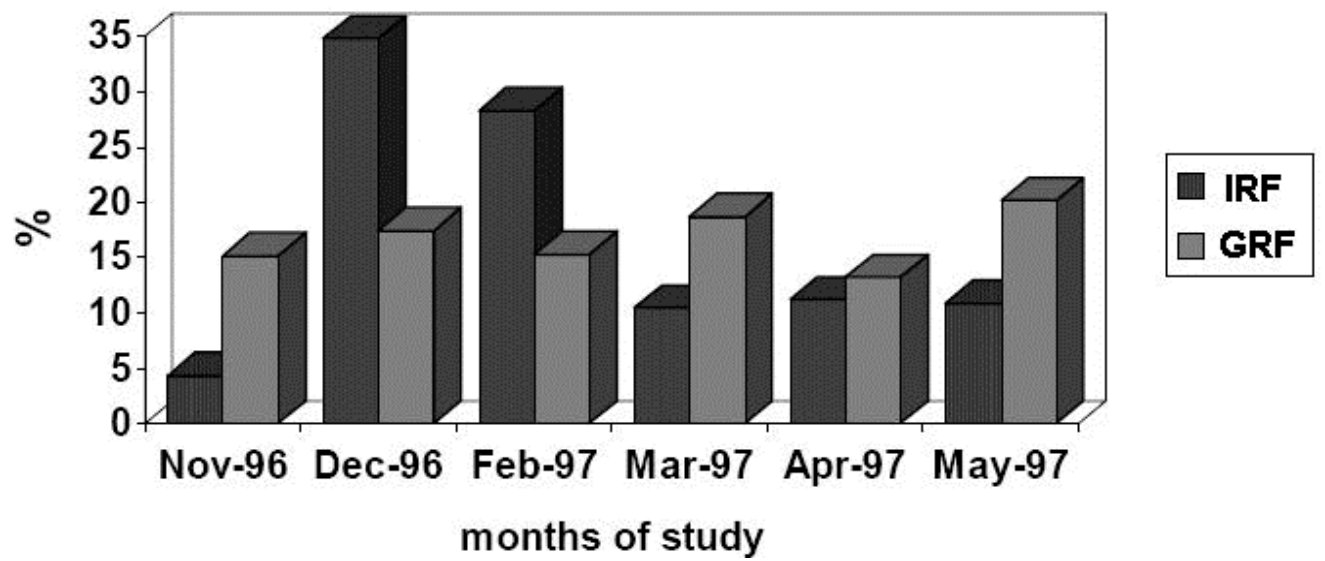

Fig. (3). Relative frequencies of occurrence time observed for the feeding strategies IRF (Individual Random Feeding) and GRF (Group Random Feeding) utilized by Guiana dolphins (Sotalia guianensis) in the North Bay of Santa Catarina, during months of study. 


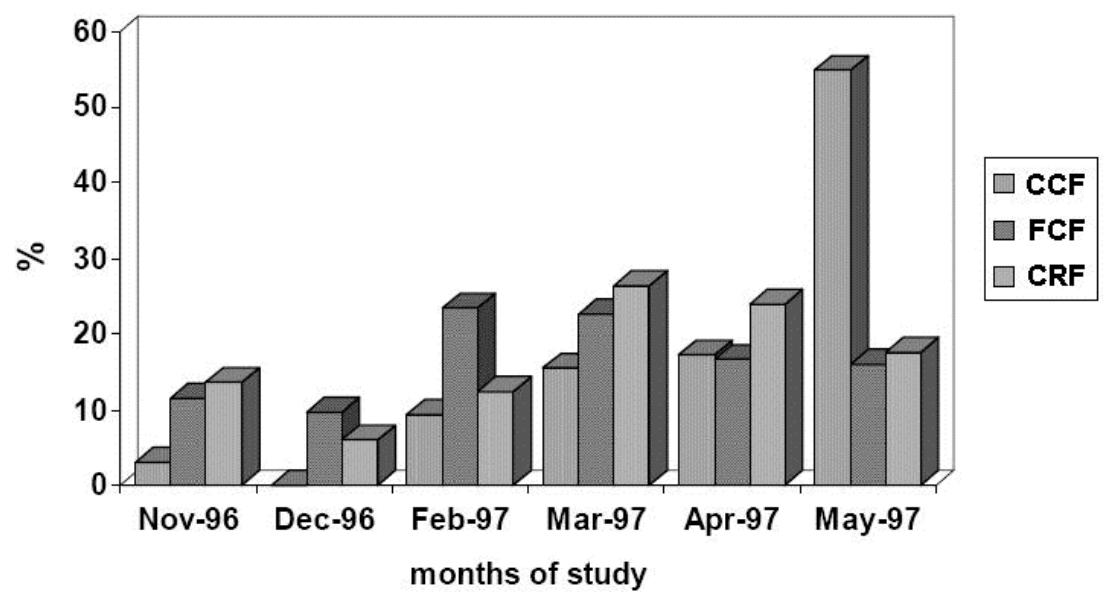

Fig. (4). Relative frequencies of occurrence time observed for the feeding strategies CCF (Circular Cooperative Feeding), FCF (Front Cooperative Feeding) and CRF (Crossing Cooperative Feeding) utilized by Guiana dolphins (Sotalia guianensis) in the North Bay of Santa Catarina, during months of study.

capture. It is well registered the occurrence of six feeding strategies to $S$. guianensis in the North Bay, that are different among them, in terms of interdependence or coordination of individuals, group cohesion, movement patterns, prey availability and environmental features.

These strategies can occur isolated, one by one each time, or combined, changing continuously during the feeding activity. It is demonstrated the great exploratory capability of these animals, which permit them to react effectively to changes in the biotic variables (prey species, their behavior and availability), environmental conditions, human interference and other variables alluded to their self group organization in the moment of the feeding activity (for example, the number of participating individuals in each strategy). The flexibility and dynamism in the dolphins' feeding activity was also cited by [3] and [40].

Studies with Tursiops truncatus in various regions (e.g. $[3,11,40,41])$ revealed that their group structure and social behavior are intimately connected with the type of habitat in which the species live, resulting in different feeding regimen and social behavior. [42] found that feeding categories, including arrangement and movements, of Tursiops truncatus are related to the spatial arrangement of their prey.

To $S$. guianensis, in the North Bay of Santa Catarina, the arrangement of individuals appear to occur only in function of food concentration, because fish are present all year long in the region [43], and there is no predators in the area, on the contrary of commented by [44] to $T$. truncatus in Argentina. However, [45] found that the group organization and behavioral patterns of Guiana dolphins in the North Bay are linked to seasonal environment cycles, such as the fluctuations in the abundance of dominant prey species.

In the present study, the fact that GRF had been the most frequent and discriminated from other strategies can be understood as an intermediate feeding strategy among IRF and the other three cooperatives (CCF, FCF and CRF).

In other words, the dolphins are not founded in united group (s) neither totally individualized. So, the GRF can represent an organization that offers more plasticity, because sometimes the animals can separate or regroup according to needs dictated by changes in the environment.

Feeding activity happen in three phases: the search, detection and capture. Although it is very difficult to separate fish detection from the capture, they are considered two main phases: the search and the capture. The search for fish,

performed by a group of dolphins is indicated by changes in the movement direction $[3,41]$. It is possible that the GRF does include the search phase too, in which the individuals keep on moving in different directions to better explore the activity's area.

In the capture phase, it is interesting that a dolphin moves actively and interact very close to the other members of the group, since the success of each attack is very dependant of the restriction of the prey's activity and movement [3]. So, this placement suggests the advantage of the cooperative feeding strategies.

During the FCF, the entire dolphin's band surrounds the fish school in order to unit the fish gradually. When the preys present a good cohesion, the dolphins can move separately to attack, in a maximization of capture. It is possible that the conducting occurs from deeper areas to more shallow waters, possibly decreasing the escape ability of the preys. This strategy was described as "Barrier method" by [3]. [31] comments a similar situation, described as "persecution in accentuated declivity areas", for the same species in Cananéia region, Southeastern Brazil.

CRF has probably the goal of sharing the school, confusing the fish, which still remain surrounded by dolphins crossing each other in the activity zone, increasing the possibility of success during the attack and capture.

Regarding to the $\mathrm{CCF}$, the dolphins forming the circle, unite the school gradually too, making possible a more efficient attack. It is possible to occur a school desegregation after the initial attack [29]. The circle is formed by animal's alternation, some surrounding and some attacking and this possible desegregation give advantage to the dolphins that are in the outsider line of the circle. The occurrence of circle 
formation in sequences may be understood as an action directed to escaping fish from the anterior circle [3].

The occurrence of Zig- zag Cooperative Feeding (ZCF), was observed just one time, apparently a rare strategy, that contribute to the complex and varied feeding strategies' repertory of $S$. guianensis in the study area. Similar strategy, but with less involved individuals was cited by [31], like a common strategy used by $S$. guianensis in Cananéia study area.

In the North Bay, strategies alternating and interchanging with traveling and resting behaviors may represent: a) the individuals are moving to other feeding site, in the case of CRF or FCF with GRF; b) They are out of their foraging maximum activity, feeding occasionally, in case of alternating IRF and GRF.

Equal benefits in group feeding in dolphins is distributed in the manner that the individuals in front of the band, when pursuing the preys, can have higher chances to capture than the ones behind. On the other hand, different individuals can occupy frontal positions during different persecutions, establishing, in this way, a rotation. This fact can possibly influence the time spent in feeding activity, in order to be satisfactory for sufficiently feed all individuals.

Here it is suggests more efforts in combining feeding behavior studies and acoustic monitoring (e.g. [46]), and realize comparative studies among populations along $S$. guianensis distribution to evaluate about influences of environmental features of the habitat in pattern behaviors, including feeding strategies.

\section{ACKNOWLEDGMENTS}

We would like to thank Paulo C. Simões- Lopes for useful discussions about this work, Jeffrey Podos for several readings and suggestions to improve early versions of this paper, and José T. Palazzo Jr for the initial encouragement and the logistical support from the International Wildlife Coalition/ Brasil. Daniel and Francisco Rossi Santos helped in the field data collection. The research and conservation program of the marine Sotalia (Projeto Golfinho Sotalia) has been funded by various sources. The work reported here was partially funded by the Whale and Dolphin Conservation Society (England), Fundação $\mathrm{O}$ Boticário de Proteção à Natureza (Brasil) and Cetacean Society International (USA).

\section{REFERENCES}

[1] Inman AJ, Krebs J. Predation and group living. Trends Ecol Evol 1987; 2: 31-32.

[2] Alcock J. Animal behavior: an evolutionary approach. Sunderland, Massachusets, Sinauer Associates 1993.

[3] Bel'kovich VM, Ivanova EE, Yefremenkova OV, Kozarovitsky LB, Kharitonov SP. Searching and hunting behavior in the bottlenose dolphin (Tursiops truncatus) in the Black Sea. In: Pryor K, Norris KS, Eds. Dolphin Societies - Discoveries and Puzzles, San Diego, Univ. of Cafifornia Press 1991.

[4] Wells RS, Scott MD. Bottlenose Dolphin Tursiops truncatus (Montagu, 1821). In: Hidgway SH, Harrison R, Eds. Handbook of Marine Mammals, vol. 6, the Second Book of Dolphins and Porpoises, San Diego, Academic Press 1999.

[5] Nowacek DP. Sequential foraging behaviour of bottlenose dolphins, tursiops truncatus, in Sarasota Bay, Florida. Behaviour 2002; 139: 1125-1145.

[6] Burgess EA. Foraging ecology of common dolphins (Delphinus sp.) In the Hauraki Gulf, New Zealand. Albany, Massey University, Master's Dissertation 2006.
[7] Ford JKB. Acoustic behavior of resident killer whales (Orcinus orca) off Vancouver Island, British Columbia. Can J Zool 1989; 67:727-745.

[8] Baird RW. The Killer whale: foraging specializations and group hunting. In: Mann J, Connor RC, Tyack PL, Whitehead H, Eds. Cetacean societies: field studies of dolphins and whales. Chicago, University of Chicago 2000.

[9] Domecini P, Batty RS, Simila T, Ogam E. Killer whales (Orcinus orca) feeding on schooling herring (Clupea harengus) using underwater tail- slaps: Kinematic analyses of field observations. J Exp Biol 2000; 203 (2): 283-294.

[10] Nottestad L, Ferno A, Axelsen BE. Digging in the deep: Killer whales' advanced hunting tactic. Pol Biol 2002; 25: 939-941.

[11] Shane SH, Wells RS, Würsig B. Ecology, behavior and social organization of the bottlenose dolphin: a review. Mar Mamm Sci 1986; 2 (1): 34-63.

[12] Moller LM, Harcourt RG. Social dynamics and activity patterns of bottlenose dolphins, Tursiops truncatus, in Jervis Bay, Southeastern Australia. Proceed Linn Soc New S Wales 1998; 120 (0): 181-189.

[13] Connor RC. Individual foraging specializations in marine mammals: Culture and ecology. Beh Brain Sci 2001; 24: 327-330.

[14] Gazda SK, Connor RC, Edgar RK, Cox F. A division of labour with role specialization in group-hunting bottlenose dolphins (Tursiops truncatus) off Cedar Key, Florida. Proceed Roy Soc B. 2005; 6272: 135-140.

[15] Connor RC, Smolker R, Bejder L. Synchrony, social behaviour and alliance affiliation in Indian Ocean bottlenose dolphins, Tursiops aduncus. Anim Beh 2006; 72 (6): 1371-1378.

[16] Norris KS, Dohl J P. Behavior of the hawaiian spinner dolphin, Stenella longirostris. Fish Bull US 1980; 77: 821-849.

[17] Benoit-Bird KJ, Au WWL. Cooperative prey herding by the pelagic dolphin, Stenella longirostris. J Acoust Soc Am 2009; 125 (1): 125-137.

[18] Bordino P, Thompson G, Iñiguez M. Ecology and behavior of the franciscana (Pontoporia blainvillei) in Bahia Anegada, Argentina. J Cet Res Manage 1999; 1(2) 213-222.

[19] Whitehead H. Structure and stability of humpback whale groups off Newfoundland. Can J Zool 1983; 61: 1391-1397.

[20] D' Vincent, CG, Nilson RM, Hanna RE. Behavior of the Humpback Whale in Southeastern Alaska. Sci Rep Whales Res Inst 1985; 36: 41-47.

[21] Clapham PJ. The humpback whale: seasonal feeding and breeding in a baleen whale. In: Mann J, Connor RC, Tyack PL, Whitehead H, Eds. Cetacean societies: field studies of dolphins and whales. Chicago: University of Chicago 2000.

[22] Herzing DL, Johnson CM. Interspecific interactions between Atlantic spotted dolphins (Stenella frontalis) and bottlenose dolphins (Tursiops truncatus) in the Bahamas, 1985- 1995. Aqu Mamm 1997; 23 (2): 85- 89.

[23] Geise L. The correct use of the vernacular names for South American dolphins genus Sotalia Gray (Mammalia, Cetacea, Delphinidae). Revta Bras Zool 2006; 23 (4): 1275-1276.

[24] Caballero S, Trujillo F, Vianna JA, et al. Taxonomic status of the genus Sotalia: species level ranking for "tucuxi" (Sotalia fluviatilis) and "costero" (Sotalia guianensis) dolphins. Mar Mamm Sci 2007; 23(2): 358-386.

[25] Flores PAC, Bazzalo M, Caballero S, et al. Proposed English common name of Sotalia guianensis to the IWC List of Recognised Cetacean Species. Scientific Committee of the IWC/60/SM16. $2008 ;$ p. 3.

[26] Borobia M, Siciliano S, Lodi L, Hoek W. Distribution of the South American dolphin Sotalia fluviatilis. Can J Zool 1991; 69: 10251039.

[27] Carr T, Bonde RK. Tucuxi (Sotalia fluviatilis) occurs in Nicaragua, $800 \mathrm{Km}$ north of its previously known range. Mar Mamm Sci 2000; 16(2): 447-452.

[28] Simões-Lopes PC. Ocorrência de uma população de Sotalia fluviatilis Gervais, 1853 (Cetacea, Delphinidae) no limite sul de sua distribuição, Santa Catarina, Brasil. Biotemas 1988; 1: 57-62.

[29] Borobia M. Comportamento e aspectos biológicos dos botos da Baía de Guanabara, Sotalia sp. Rio de Janeiro, Uni Est RJ, Bachelor's Monography 1984.

[30] Geise L, Gomes N, Cerqueira R. Behavior, habitat use and population size of Sotalia fluviatilis (Gervais, 1853) (Cetacea, Delphinidae) in the Cananéia estuary region, São Paulo, Brazil. Rev Brasil Biol 1999; 59 (2): 183-194. 
[31] Monteiro-Filho ELA. Comportamento de caça e repertório sonoro do golfinho Sotalia brasiliensis (Cetacea: Delphinidae) na região de Cananéia, Estado de São Paulo. Campinas, Unicamp, Ph.D Thesis 1991.

[32] Oliveira SMC, Rosso S, Siciliano S, Zerbini AN, Zampirolli E, Vicente A, Alvarenga F. Behavioral observations of the marine tucuxi dolphin (Sotalia fluviatilis) in São Paulo estuarine waters. Aq Mamm 2000; 26 (3): 260- 270.

[33] Rossi-Santos MR, Wedekin LL, Monteiro-Filho ELA. Residence and site fidelity of Sotalia guianensis in the Caravelas River Estuary, eastern Brazil. J Mar Biol Ass UK 2007; 87: 207-212.

[34] Geise L. Estrutura social, comportamental e populacional de Sotalia sp ( Gray,1886) (cetacea, Delphinidae) na região estuarinolagunar de Cananéia, SP e na Baía de Guanabara, RJ. São Paulo, USP, Master Sci Dissertation 1989.

[35] Flores PAC. Observações sobre comportamento, movimentos e conservação do golfinho ou boto Sotalia fluviatilis (Gervais, 1853) (Mammalia- Cetacea- Delphinidae) na Baía Norte de Santa Catarina, SC, Brasil. Florianópolis, UFSC, Bachelor's Monography 1992.

[36] Da Silva VMF, Best RC. Sotalia fluviatilis. Mamm Species 1996; 527: 1-7.

[37] Flores PAC. Preliminary results of a photoidentification study of the marine tucuxi, Sotalia fluviatilis, in southern Brazil. Mar Mamm Sci 1999; 15 (3): 840-847.

[38] Queiroz REM, Ferreira RG. Sampling interval for measurements of estuarine dolphins' (Sotalia guianensis) behaviour. JMBA2 Biodiversity Records Published on-line 2008.
[39] Lehner PN. Handbook of ethological methods, $2^{\text {nd }}$ ed. Cambridge, Cambridge University Press 1996.

[40] Bearzi G, Politi E, Di Sciara GN. Diurnal behavior of free- ranging bottlenose dolphins in the Kvarneric (northern Adriatic Sea). Mar Mam Sci 1999; 15 (4): 1065-1097.

[41] Shane SH. Behavior and ecology of the bottlenose dolphin at Sanibel Island, Florida. The Bottlenose Dolphin. In: Leatherwood S, Reeves RR, Eds. San Diego, Academic Press 1990; pp. 245-265.

[42] Acevedo-Gutierrez A, Parker N. Surface behavior of bottlenose dolphins is related to spatial arrangement of prey. Mar Mam Sci 2000; 16 (2): 287-298.

[43] Paula GS. A pesca artesanal na Ilha de Santa Catarina e seu impacto na população de catáceos da costa catarinense. Florianópolis, Univ Fed Sta Catarina, Master's Dissertation 1992.

[44] Wursig B, Wursig M. Behavior and ecology of the bottlenose dolphin, Tursiops truncatus, in the south Atlantic. Fish Bull US 1979; 77: 399-412.

[45] Daura-Jorge FG, Wedekin LL, Piacentini VQ, Simões-Lopes PC Seasonal and daily patterns of group size, cohesion and activity of the estuarine dolphin, Sotalia guianensis (PJ van Bénéden) (Cetacea, Delphinidae) in southern Brazil. Revta Bras Zoo 2005; 22 (4): 1014-1021.

[46] Penin-Garcia FC, Rossi-Santos MR. Caracterização preliminar dos assobios do boto cinza Sotalia guianensis (van Bénéden, 1864), no estuario do rio Caravelas, extremo sul do estado da Bahia, Brasil. Primera Reunión Internacional sobre el Estudio de Mamíferos Acuáticos SOMEMMA-SOLAMAC. Mérida, México 2006. 